\title{
Trade and the conservation status of the family Psittacidae in Venezuela
}

\author{
PHILIP DESENNE and STUART D. STRAHL
}

\begin{abstract}
Summary
An assessment of trade in parrots throughout Venezuela, 1988-1989, reveals alarmingly high internal and international levels. The national trade has main outlets in major cities, but is now compounded by the use of feathers for Indian artifacts sold to tourists. International trade involves illegal export chiefly from the Orinoco Delta, the majority of such birds $(65,000-75,000)$ destined for Guyana. The large macaws suffer badly from both types of trade, but owing to its restricted range the endemic Amazona barbadensis is perhaps the most critically threatened species. Other species are assessed and, along with key sites, identified in priority order for remedial action, which should include more detailed field studies, rigorous trade data analysis, exchange of trade data with major neighbours, census and monitoring technique improvements, educational campaigns, and strict breeding facility control.
\end{abstract}

Un estudio sobre el comercio de periquitos en Venezuela 1988-1989 ha revelado un nivel alarmante de comercio nacional e internacional. La red de comercio nacional tiene puntos de venta importantes en las ciudades principales. Comercio ha incrementado debido al uso de plumas en artefactos indios de venta a turistas. El comercio internacional consiste principalmente en la exportación ilegal de periquitos de la Delta de Orinoco, la mayoría $(65,000-75,000)$, destinados a Guayana. Los periquitos grandes se ven muy afectados por los dos tipos de comercio, pero dado su muy limitada distribución, el endémico Amazona barbadensis es talvez la especie más amenazada. Se estudia otras especies y se identifica sus respectivas distribuciones en orden de prioridad para acción. Acción debe incluir estudios de campo más detallados, un análisis riguroso de datos sobre comercio, intercambio de esta información con países vecinos, el mejoramiento de técnicas de censo y observación, campañas educacionales, y control estricto sobre facilidades de cría.

The family Psittacidae is represented in Venezuela by 14 genera and 49 species of macaws, parrots, parakeets, and parrotlets. The total includes roughly $38 \%$ of the Neotropical species. Psittacids are found throughout all habitat types in the country (Meyer de Schauensee and Phelps 1978), ranging from sea level in insular and coastal arid scrubland to 3,000 $+\mathrm{m}$ in the "páramos" (highlands) of the Andes. They also occur in the lowland tropical savannas and gallery forests of the central plains (or "llanos"), cloud-forests of the northern cordilleras, tropical humid forests, rainforests and the $2,500+\mathrm{m}$ tabletop mountains ("tepuis") of Bolivar and Amazonas states.

North of the Orinoco River, the destruction of primary forests has reduced available habitat for some psittacid species to small, isolated fragments. This reduction of natural ecosystems is considered critical in extensive areas along the 
coastal cordillera, the Andes, and in parts of the llanos (Bisbal 1988). While habitats south of the Orinoco River remain relatively continuous and stable, uncontrolled mining, logging and non-sustainable agriculture is beginning to affect many previously untouched forests (Novo 1986, Bisbal 1988).

Along with this habitat destruction, a major cause of the decline of psittacid populations in Venezuela has been the national and international pet trade. Theoretically the Psittacidae, along with all song and ornamental birds, are protected under the Venezuelan Wildlife Protection Law (Ley de Protección a La Fauna Silvestre 1970), which forbids hunting, trading or transporting non-game species. Unfortunately the law does not forbid ownership, and it is therefore legally possible to maintain a wild-caught psittacid, provided the owner does not transport or attempt to sell it.

Legal action against trading is minimal in comparison to the extent of the traffic and level of commercialization. In general, the reasons for this are a lack of awareness of the severity of the illegal trade situation and the widespread cultural acceptance in Venezuela of psittacids as pets, which dates as far back as the Precolombian ancestors, the Cumanagotos (DeCivrieux 1980). Certain members of this family have always been persecuted for the national trade, but in recent years (since the devaluation of the national currency in 1983) international trading has increased by many orders of magnitude. This illegal commerce, especially where combined with habitat destruction, is the major contributor to the reduction in numbers of the Psittacidae in Venezuela. Due to a lack of information and growing concern over this threatened family, in January 1988 we began a national survey on the population status, use in local and international trade, and biology of the Venezuelan Psittacidae. Having worked on the project for nearly 18 months, we present here the preliminary results on the conservation status of the Psittacidae in Venezuela.

\section{Study areas and methods}

Our study sites are widely spread throughout Venezuela, concentrating mostly on protected areas such as national parks, wildlife refuges and forest reserves, with several other sites on private lands (Figure 1 ). To date, locations in protected areas have been visited in south-eastern (Canaima National Park), northeastern (Paria N.P. and Araya Peninsula, Guácharo N.P. and surrounds, Delta Amacuro, Margarita Island), south-central (Caura Forest Reserve), central (Guarico state), north-central (Miranda state, Yacambu N.P., San Esteban N.P., Terepaima N.P., Avila N.P., Cuare Wildlife Refuge, Morrocoy N.P.), and western (Sierra Nevada N.P., La Azulita, Mérida state) Venezuela.

In each location, relative abundances were estimated from variable-width line transects (Emlen 1971) and variable circular plots (Reynolds et al. 1980), and local trade in psittacids was qualitatively investigated via interviews with residents and enforcement personnel and by visits to local markets. 


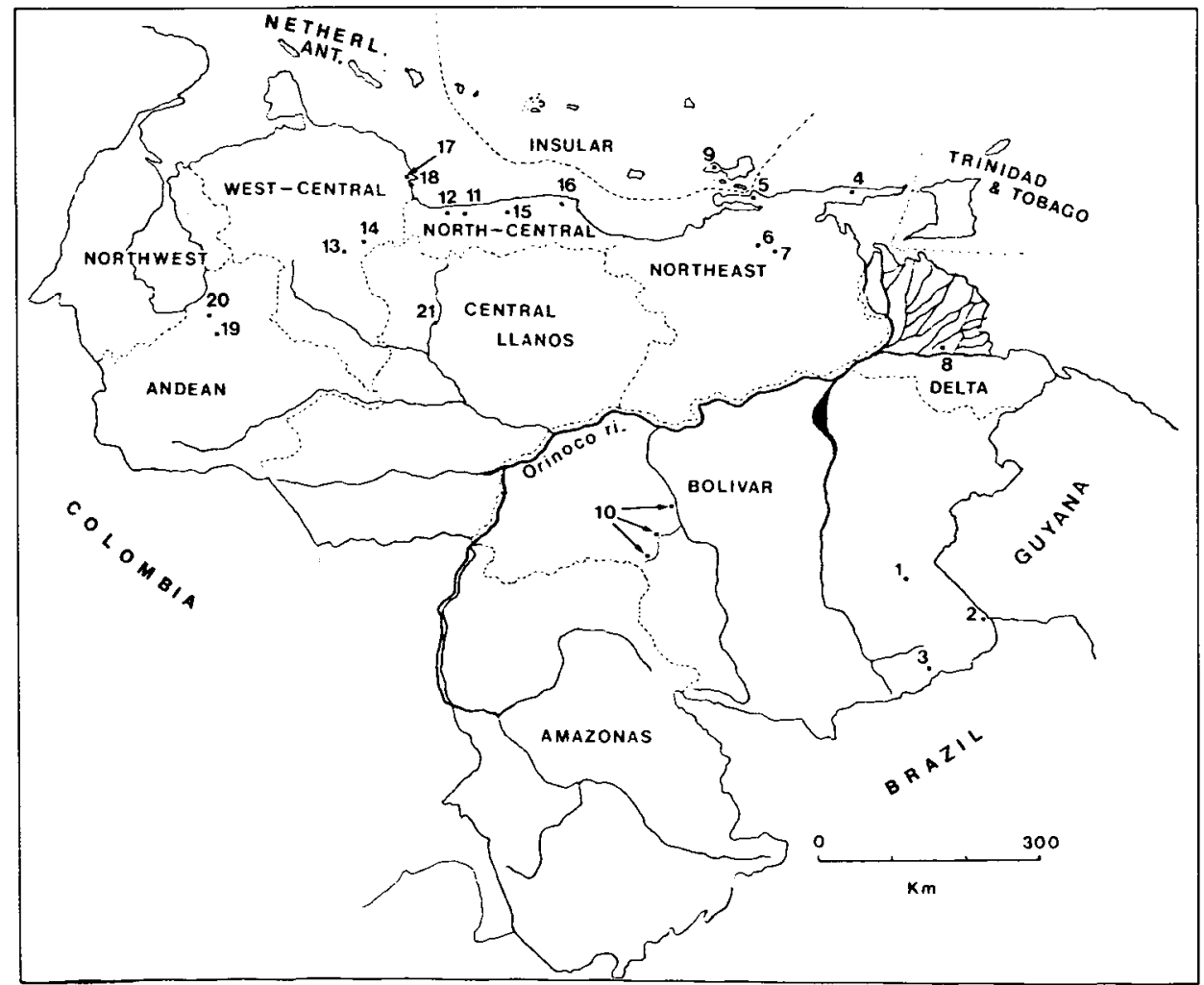

Figure 1. Regional divisions and study sites. Dotted lines, regional divisions; solid lines (within Venezuela), main rivers. Study sites: Canaima N.P. (1,2,3); Paria N.P. (4); Araya Peninsula (5); Guácharo N.P. and surrounds (6,7); Delta Amacuro (8); Margarita Island (9); Caura Forest Reserve (10); Henri Pittier N.P. (11); San Esteban N.P. (12); Yacambu N.P. (13); Terepaima N.P. (14); Avila N.P. $(15,16)$; Cuare Wildlife Refuge (17); Morocoy N.P. (18); Sierra Nevada N.P. (19); La Azulita (Sierra La Culata) (20); Hato Masaguaral (private ranch in the "llanos") (21).

\section{Results}

\section{Illegal trade}

A large-scale illicit trade in Psittacidae occurs throughout Venezuela. High-trade areas are not necessarily located where there is greatest diversity and abundance of psittacids but are determined more by their accessibility (Table 1). The central llanos, the northern coastal regions, and the north of Bolivar state are the areas that supply most of the psittacids for the national trade. Psittacids for international trade come mainly from the delta of the Orinoco River (Cabrera in press), the north-west, and west along the Colombian border, and some from the Caribbean Islands. Outside of these areas the trade apparently remains very local. The peak period for both national and international trade follows the breeding seasons of major species. The main supply of birds is composed of 
Table 1. Regional diversity and relative levels of national and international trade in Psittacidae in Venezuela

\begin{tabular}{|c|c|c|c|c|c|c|}
\hline \multirow[t]{2}{*}{ Region } & \multirow{2}{*}{$\begin{array}{c}\% \text { of } \\
\text { total area }\end{array}$} & \multirow{2}{*}{$\begin{array}{l}\text { No. of } \\
\text { genera }\end{array}$} & \multirow{2}{*}{$\begin{array}{l}\text { No. of } \\
\text { species }\end{array}$} & \multirow{2}{*}{$\begin{array}{c}\text { Diversity } \\
\text { rank }\end{array}$} & \multicolumn{2}{|c|}{ Levels of trade } \\
\hline & & & & & Nat & Int \\
\hline Bolívar & $26 \cdot 0$ & 12 & 31 & 1 & ++ & + \\
\hline North-east & 9.2 & 10 & 20 & 2 & ++ & ++ \\
\hline South (Amazonas) & $19 \cdot 3$ & 11 & 19 & 3 & ++ & + \\
\hline Andean & $7 \cdot 5$ & 11 & 17 & 4 & + & + \\
\hline North-west Perijá & 6.9 & 9 & 17 & 5 & +++ & ++ \\
\hline Central Llanos & $17 \cdot 0$ & 6 & 16 & 6 & +++ & ++ \\
\hline West-central & $7 \cdot 3$ & 8 & 15 & 7 & + & - \\
\hline North-central coast & 1.8 & 8 & 15 & 7 & + & ++ \\
\hline Orinoco delta & $4 \cdot 4$ & 7 & 12 & 8 & ++ & +++ \\
\hline Insular & 0.1 & 4 & 6 & 9 & ++ & ++ \\
\hline
\end{tabular}

young taken from the nest in the mid-late nestling stage. However, many macaws and larger amazons are captured as adults.

\section{National trade}

National trade routes usually follow the main highway system leading to large cities (Figure 2). Psittacids are purchased cheaply in rural source areas and transported for sale to urban centres. In Caracas, main distributors bring parrots by the hundreds on a bimonthly basis during the high-trade season (April to July). Some years the high season extends until September or October, and the birds sold during this season are usually young and featherless.

Large dealers are often associated with major pet shops in the city. These shops serve as mediators for undercover business done from private apartments, which are often owned by their personnel. Main dealers also distribute smaller amounts of birds to private independent dealers, who sell them via newspaper advertisements or by word of mouth. Small-time dealers normally lack experience and facilities to care for birds and sell them at low prices to maintain a higher turnover rate ( $P$. de Mieres pers. comm.).

A small-scale roadside commerce of birds also exists throughout the country, mostly by children and adolescents along busy highways connecting areas of high tourism. The impact of this form of trade is small but not negligible; it can have adverse effects on local psittacid populations, such as Amazona barbadensis (Appendix I of CITES) along coastal areas and A. ochrocephala in the llanos. To cite an example, on Margarita Island the vast majority of the fishermen living on the western peninsula (Macanao) owned one or two A. barbadensis as pets. They conversed openly about capture techniques and also mentioned how these parrots have become increasingly rare with each passing year.

Recently there has been a dramatic increase in a different type of impact on populations of Psittacidae and other ornamental species. A growing demand from the tourist sector for "Indian artifacts" is beginning to affect local psittacid populations, especially those south of the Orinoco River (Gorzula and Medina- 


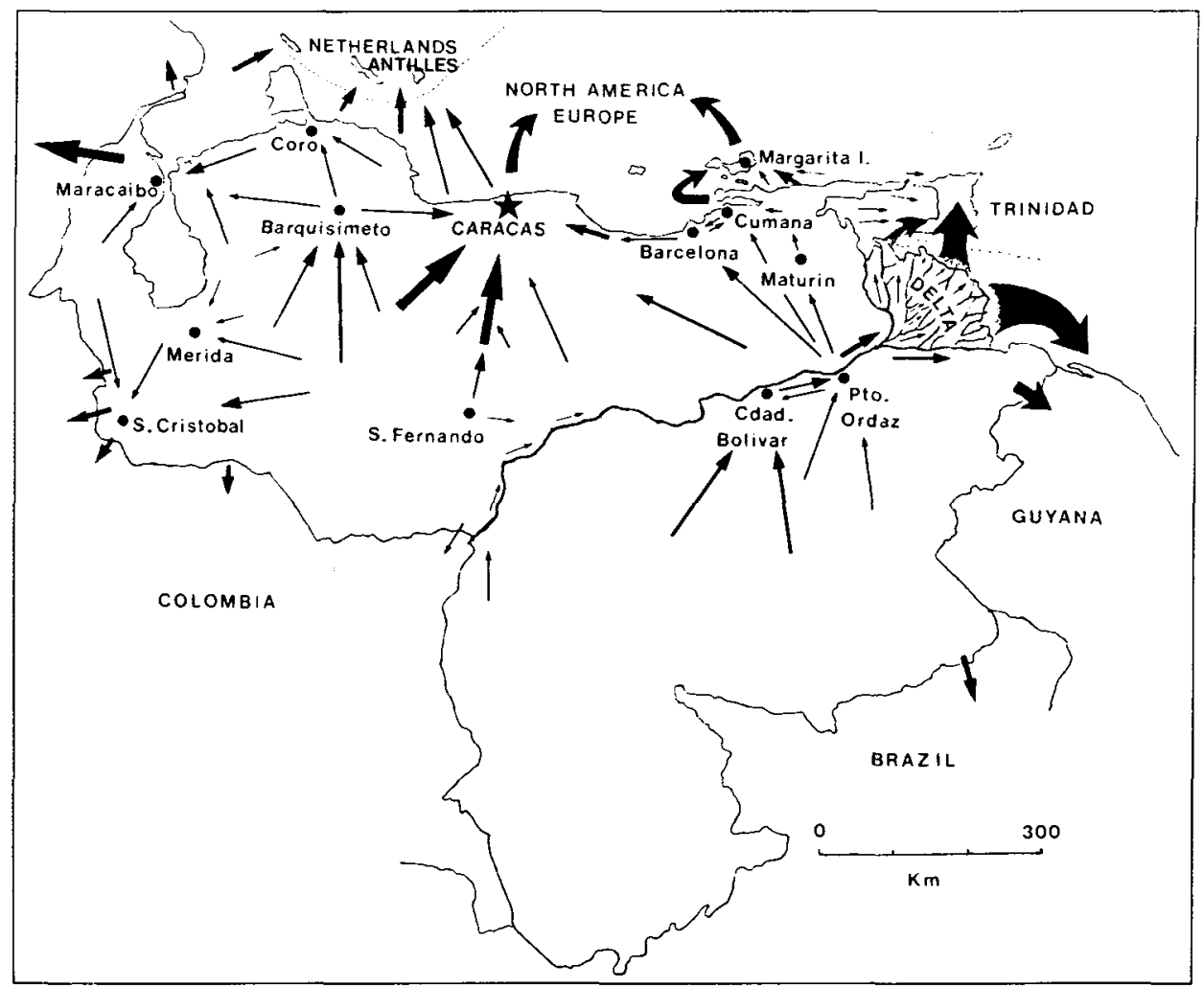

Figure 2. Major illegal national and international trade routes for Psittacidae. Width of arrows represents relative levels of trade.

Cuervo 1986, Strahl and Desenne unpublished data). Psittacids, toucans Ramphastidae and several other groups are hunted for their feathers in rural areas to make handicrafts. These are purchased cheaply in the states of Amazonas and Bolivar and are sold in urban tourist shops for exorbitant prices. These artifacts often have nothing to do with the more typical indigenous handicrafts (Gorzula and Medina-Cuervo 1986), and they are being confiscated in increasing numbers by the PROFAUNA section of the Venezuelan Ministry of the Environment (S. Boher and J. G. García pers. comm.).

\section{International trade}

The majority of Venezuelan Psittacidae in the international pet market leave the country from the delta of the Orinoco River (Cabrera in press). This illegal traffic is primarily carried out by the Warao Indians, who sell to wildlife traders from Guyana and Trinidad. Data from confiscations by the Venezuelan National Guard indicate that more birds are being smuggled out from the northern half of the delta than in the south-east (Figure 2) (Barreto 1986 and pers. comm.). However, a recent survey by PROFAUNA/MARNR suggests that the majority of 
the illegal traffic is destined for Guyana (J. Cabrera and J. G. García pers. comm.).

While it is hard to quantify the actual numbers leaving from each half of the region, a conservative estimate suggests that during the high-trade season (February to June) at least 50,000 psittacids are exported at a rate of 10,000 birds per month. This figure is obtained by calculating an average of 25 boats per week leaving the delta with 100 parrots in each (numbers taken from Barreto 1986 and pers. comm.). We believe this to be a conservative estimate, as the National Guard have captured single boatloads containing more than 600 psittacids.

Available data suggest that figures for the low-trade season are only half or one third of those for the high-trade season. We estimate that between 65,000 and 75,000 psittacids are exported yearly from the delta alone. Considering the alleged destination of these birds, it is highly likely that a major portion of the legal export quotas for Psittacidae established by Guyana - over 36,0oo in the previous year (Thomsen 1988) - are filled by illegally exported Venezuelan birds. The destination of surplus birds is probably the illegal international market via both Guyana and Trinidad.

Psittacids are also being exported in lower numbers from the northern coast and Margarita Island to other Caribbean Islands, North America, Europe, and to Colombia as well. The Sierra de Perijá and the Guajira Peninsula in Zulia state and the western Colombian border through Táchira state is another centre for international trade (S. Boher pers. comm.). Psittacidae smuggled across the border in these regions frequently enter the European and North American markets through the Colombian ports of Cartagena and Barranquilla.

In addition, illegal shipments of parrots and macaws depart directly from the Venezuelan mainland. Confiscations have recently been made of hundreds of parrots and macaws destined for Europe (especially Spain and the Canary Islands) from the Maiquetia (Caracas) airport, and other shipments apparently pass through Venezuela on flights originating in Brazil (Manaus) and elsewhere (Iquitos) (S. Boher pers. comm.). Trade in Psittacidae from the Paria Peninsula in the north-east is both through the free port of Margarita and directly to Trinidad (K. Silvius pers. comm.). Some small-scale international trade in parrots and macaws leaves for the Netherlands Antilles from several points along the Venezuelan coast, often on ships filled with commercial goods (B. de Boer pers. comm.). Although it appears that the extent of international trade in other regions within Venezuela is considerably less than for the delta, it still can pose a significant threat to insular and restricted populations such as Amazona barbadensis and some Ara species.

\section{Capture methods}

As in most parts of South America, the most popular capture methods for psittacids in Venezuela are by cutting nest-trees or hacking open nest cavities (Forshaw 1978, Nilsson 1981). On Margarita Island, the increasing scarcity of $A$. barbadensis has caused locals to abstain from felling nest-trees in order to assure a recapture the following year. Instead, they use a barbed leaf (Bromelia chrysantha or B. humilis) or a fishing hook to extract the featherless chicks.

In the delta of the Orinoco River psittacids are captured using a more sophisti- 
cated method, similar to that described by Jeffreys (1760 in Snyder et al. 1987). The technique, used by the Warao Indians, involves two persons. One climbs a tall palm tree with a tame parrot or macaw, called a "pitador" (whistler), which he tethers to an exposed perch. The Indian then conceals himself under the palm fronds and waits for a flock of wild parrots to fly by. When a flock is heard or seen, the Indian elicits calls from the "pitador", thereby attracting the wild birds into the tree. The parrots are snared individually as they settle in the palm, using a noose attached to a long stick, and are bound and dropped to the Indian waiting below. Often the Indians can capture most birds in a flock using this technique. These birds are sold either to non-Indian colonists, who accumulate large quantities in key areas for Guyanan or Trinidadian traders, or directly to the traders by the Indians themselves (Barreto 1986 and pers. comm.). This method is by far the most damaging to large psittacid populations in the delta, and its efficiency explains the large quantities being exported year-round.

A common capture technique used throughout Venezuela for smaller psittacids is to lure flocks into mist-nets with tame birds. Another (used in the Andes) consists of spreading a special glue derived from tree saps on the branches of a common roost site to immobilize the birds.

\section{Commercial species}

Venezuelan psittacids on the market are shown in Table 2. Amazona ochrocephala is the preferred species due to its linguistic skills, and is the most expensive of the amazon parrots within the country. A. amazonica accounts for the majority of sales, as it is less verbally skilled and therefore only half the price of ochrocephala. The threatened $A$. barbadensis is also available along the western and eastern coasts and on the island of Margarita.

The large macaws are the most sought-after Venezuelan psittacids due to their size and colour, but they are available only locally. Since 1984 large macaws have been increasingly rare on the national market due to the demand from international trade (P. de Mieres pers. comm.). Nevertheless, the Military Macaw Ara militaris is still somewhat common in the capital because it occurs in areas nearby. The smaller macaws, particularly Ara severa, are becoming commoner in national trade. Smaller psittacids, such as Aratinga pertinax, Brotogeris jugularis and Forpus passerinus, are heavily commercialized as cheap alternatives to the much more expensive parrots and macaws.

For the international trade, the large macaws are the preferred psittacid for exportation due to the high prices foreign dealers offer. This has led to the drastic reduction of some local populations. In the delta, the previously common Blue-and-yellow Macaw Ara ararauna has been trapped so heavily that it is now considered extremely rare. The demand for large macaws is such that more adults are captured than young, further reducing the reproductive potential of populations. Smaller macaws are also being traded more frequently as the larger macaws become harder to find. Amazona parrots are also lucrative species for the export business, but interest in them is secondary to macaws. Smaller psittacids, on the other hand, are used to fill the remaining space in smuggled shipments. 
Table 2. Use of young vs. adults, use in national and international trade, and relative level of trade among the Venezuelan Psittacidae

\begin{tabular}{|c|c|c|c|c|}
\hline Species & $\begin{array}{l}\text { Use in trade of } \\
\text { adult vs. young }\end{array}$ & $\begin{array}{c}\text { Use in } \\
\text { Venezuela }\end{array}$ & $\begin{array}{l}\text { Use in } \\
\text { exports }\end{array}$ & $\begin{array}{c}\text { Relative level } \\
\text { of trade }\end{array}$ \\
\hline Amazona amazonica & $Y>A$ & VC & $\mathrm{VC}$ & +++ \\
\hline A. autumnalis & $?$ & $\mathrm{R}(\mathrm{loc})$ & $\mathrm{U}$ & $++(\log ?)$ \\
\hline A. barbadensis & $\mathrm{Y}>\mathrm{A}$ & $C$ (loc) & $\mathrm{U}$ & $+++(\mathrm{loc})$ \\
\hline A. dufresniana & $?$ & $\mathrm{R}$ & $?$ & $++(\mathrm{loc})$ \\
\hline A. farinosa & $\mathrm{Y}, \mathrm{A}$ & C & $\mathrm{C}$ & ++ \\
\hline A. festiva & A, Y & $U$ & C & ++ \\
\hline A. mercenaria & $?$ & $\mathrm{U}$ & $\mathrm{U}$ & + \\
\hline A. ochrocephala & $\mathrm{Y}>\mathrm{A}$ & VC & vC & +++ \\
\hline Ara ararauna & $A>Y$ & $\mathrm{C}$ & $\mathrm{C}$ & +++ \\
\hline A. chloroptera & Y, A & $\mathrm{C}$ & VC & +++ \\
\hline A. macao & $\mathrm{Y}, \mathrm{A}$ & $\mathrm{C}$ & VC & +++ \\
\hline A. militaris & $\mathrm{Y}, \mathrm{A}$ & $\mathrm{C}$ & $\mathrm{C}$ & $+++(\mathrm{loc})$ \\
\hline A. severa & A, Y & $\mathrm{U}$ & $U$ to $C$ & ++ \\
\hline A. manilata & $?$ & $\mathrm{U}$ & $\mathrm{U}$ & ++ \\
\hline A. nobilis & $?$ & $\mathrm{U}$ & $U$ to $C$ & ++ \\
\hline Aratinga pertinax & A, $Y$ & VC & VC & +++ \\
\hline A. acuticaudata & A, Y & C & $?$ & +++ (loc) \\
\hline A. leucophthalmus & $A>Y$ & $C(l o c)$ & VC & ++ \\
\hline A. solstitialis & $?$ & $\mathrm{U}(\mathrm{loc})$ & $\mathrm{U} ?$ & + (loc?) \\
\hline A. wagleri & $?$ & $\mathrm{U}$ & $?$ & + \\
\hline Deroptyus accipitrinus & $?$ & $\mathrm{U}(\mathrm{loc})$ & U? & + \\
\hline Bolborhynchus lineola & A & $\mathrm{R}$ & $?$ & - \\
\hline Forpus passerinus & $\mathrm{A}>\mathrm{Y}$ & VC & VC & +++ \\
\hline F. conspicillatus & $?$ & $?$ & $?$ & - \\
\hline F. sclateri & $?$ & $?$ & $?$ & - \\
\hline Brotogeris jugularis & $A>T$ & VC & $\mathbf{R}$ & +++ \\
\hline B. chrysopterus & A & $\mathrm{U}(\mathrm{loc})$ & $?$ & + \\
\hline B. cynoptera & $?$ & U & $?$ & - \\
\hline Nannopsittaca panychlora & $?$ & $\mathrm{R}(\mathrm{loc})$ & $?$ & + \\
\hline Touit batavica & A, Y? & $\mathrm{U}$ to $\mathrm{C}$ & ? & ++ \\
\hline T. purpurata & $?$ & $?$ & $?$ & - \\
\hline T. huetii & $?$ & $?$ & $?$ & - \\
\hline T. dilectissima & $?$ & $?$ & $?$ & - \\
\hline Pionites melanocephala & A & VC & C & +++ \\
\hline Pionopsitta caica & A & U (loc) & $?$ & + \\
\hline P. barrabandi & $?$ & $\mathrm{U}$ & $?$ & - \\
\hline P. pyrila & $?$ & $\mathrm{R}(\mathrm{loc})$ & $?$ & - \\
\hline Hapalopsittaca amazonina & $?$ & $\mathrm{R}(\mathrm{loc})$ & ? & - \\
\hline Pionus chalcopterus & $?$ & $\mathrm{R}$ (loc) & $?$ & $++(\operatorname{loc})$ \\
\hline$P$. fuscus & $?$ & $\mathrm{R}(\mathrm{loc})$ & $?$ & $++?$ \\
\hline$P$. menstruus & $?$ & $\mathrm{U}$ to $\mathrm{C}$ & $\mathrm{U}$ & ++ \\
\hline$P$. seniloides & $?$ & $\mathrm{U}$ & $?$ & - \\
\hline$P$. sordidus & ? & $\mathrm{U}$ & $?$ & + \\
\hline Pyrrhura egregia & $?$ & $\mathbf{R}$ & $?$ & - \\
\hline P. hoematotis & $?$ & $\mathrm{U}$ to $\mathrm{C}$ & $?$ & + \\
\hline P. leucotis & $A, Y ?$ & $\mathrm{U}$ & $?$ & + \\
\hline P. melanura & $?$ & $?$ & $?$ & - \\
\hline P. picta & A, Y? & $\mathrm{U}$ & $?$ & + \\
\hline P. rhodocephala & $?$ & $\mathrm{U}, \mathrm{C}$ (loc) & $?$ & + \\
\hline
\end{tabular}

Key: VC, very common; $C$, common; $U$, uncommon; $R$, rare; +++ , most heavily traded; ++ , heavily traded; + , traded; - , negligible trade; loc, traded on a local level. 


\section{Critical species and critical habitats}

High-priority species for conservation action in Venezuela are divided into two groups: those that are in extremely high demand as trade species and those that have restricted ranges, strict habitat requirements or occur in threatened areas. Critical species are those that have several of the above characteristics. Here we have defined these species on a national level, irrespective of their status in other countries, because we feel that national-level action on their behalf must be stimulated.

The genus Amazona contains the highest number of critical or high priority species, with seven subspecies in need of attention (Table 3). Of these, the two subspecies of $A$. barbadensis are the most critical, considering their patchy distribution on the coast and islands. We feel that the listing of this species on Appendix I of CITES, and in the ICBP world check-list of threatened birds (Collar and Andrew 1988) is fully justified. The known breeding areas (see Figure 3: Macanao Peninsula, Margarita, and La Blanquilla Islands, the Araya Peninsula, regions around Puerto Píritu, Paraguaná Peninsula, Dabajuro, and Casigua) offer no legal protection, and all known populations are under considerable pressure from local human activities. The only protected areas in which $A$. barbadensis has been sighted in small numbers is a private reserve on the Sierra de San Luis, Paraguaná Peninsula, managed by the Fundación Bioma ( $R$. Ramírez, pers. comm.).

The insular populations of $A$. barbadensis appear to be the most affected by illegal trade. A census in August 1988 of $A$. barbadensis on La Blanquilla Island, where young are taken by fishermen, revealed less than 100 individuals (J.L. Jiménez pers. comm.). Recent surveys on the Macanao Peninsula of Margarita Island (K. Silvius pers. comm., unpublished data) have estimated a probable population size of $800-1,000$ individuals. The harvesting of young to supply the local pet trade is a major impact on this island population, and the high number of confiscations of chicks in the current year by the National Guard (S. Boher pers. comm.) suggests organized efforts, perhaps indicating international commerce. Moreover, sand-mining on Macanao for the growing construction business on the island's eastern half is slowly destroying the primary foraging

Table 3. Priority Species within Venezuelan Psittacidae: Genus Amazona

\begin{tabular}{|c|c|c|c|c|c|c|}
\hline \multirow[t]{2}{*}{ Species } & \multirow[t]{2}{*}{ Status } & \multirow{2}{*}{$\begin{array}{l}\text { Size of } \\
\text { range }\end{array}$} & \multirow{2}{*}{$\begin{array}{c}\text { Habitat } \\
\text { continuity }\end{array}$} & \multicolumn{2}{|c|}{ Threats } & \multirow{2}{*}{$\begin{array}{l}\text { Action } \\
\text { priority }\end{array}$} \\
\hline & & & & Trade & $H D$ & \\
\hline A. $b$. barbadensis & Endangered & Restricted & Contin & High & High & Critical \\
\hline A. $b$. rothschildi & Endangered & Restricted & Patchy & High & High & Critical \\
\hline A. farinosa ssp. & Unknown & Restricted & Contin & High & High & Critical \\
\hline A. o. ochrocephala & Common, decl & Large & Discont & V. $\mathrm{Hi}$ & High & $\mathrm{Hi}-\mathrm{Crit}$ \\
\hline A. d. dufresniana & Uncommon & Small & Patchy & Med. & High & High \\
\hline A. m. mercenaria & Uncommon & Small & Patchy & Low & V. Hi & High \\
\hline A. m. canipalliata & Uncommon & Restricted & Patchy & Low & V. Hi & High \\
\hline
\end{tabular}

Abbreviations: HD, habitat destruction; decl, declining; V.Hi, very high; Contin, continuous; Discont, discontinuous. 


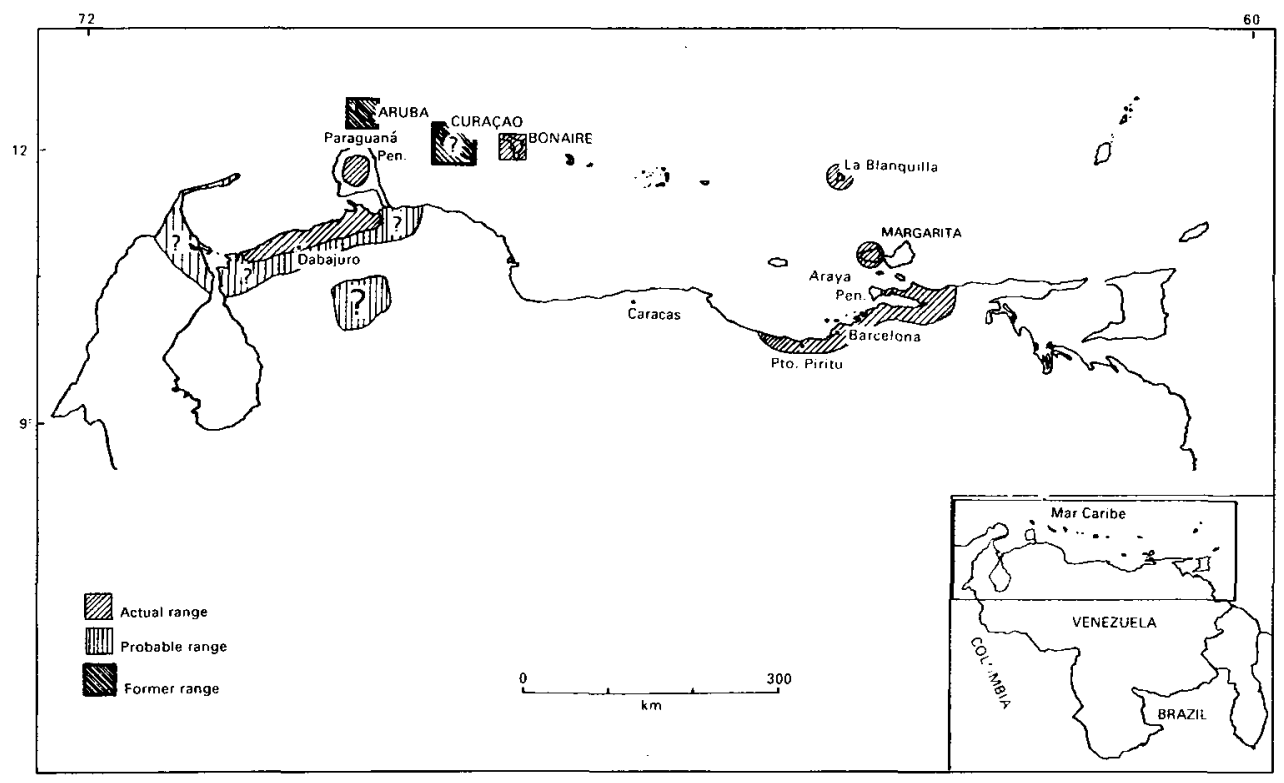

Figure 3. A map of the known distribution and breeding locations of Amazona barbadensis in Venezuela.

habitat as well as roosting areas and nesting trees of the population (K. Silvius pers. comm.). Projects are currently under way on Margarita on this species, including a detailed study of its ecology and an educational campaign involving local, national, and international conservation organizations.

Among other Amazona species, the current population status of $A$. festiva bodini is unknown, but we believe that numbers are declining throughout its range in the llanos and along the Orinoco because of habitat destruction and the pet trade. This species is particularly vulnerable in the delta region where there are no protected areas and where illegal exports and capture rates are highest. $A$. ochrocephala may soon reach threatened status within Venezuela due to the huge numbers of this species that are captured for the national and international trade. Habitat destruction is also a matter of concern throughout its range in the llanos. We have observed that local populations are declining at alarming rates in the llanos of Guarico state.

A. dufresniana is still in the category of unknown, despite being targeted for review by Ridgely (1981). On a five-week survey of south-eastern Bolivar state on the Gran Sabana, we had no sightings in the wild of the species, but three birds were seen in captivity. We suspect that population levels are quite low, and it is certainly uncommon in the areas within its range that we have visited.

A. mercenaria is of special concern due to the rapid rate of habitat destruction occurring throughout its range in the Andes and the Perija Mountains. The Sierra Nevada N.P. in the state of Mérida, the only region where $A$. $m$. canipalliata is known to occur, is among the most disrupted national parks in the country (Hernández 1988). We observed no individuals of this species during a two-week trip to the park in February 1989, and it is considered rare by locals. 
Table 4. Priority species within Venezuelan Psittacidae: genus Ara

\begin{tabular}{lllllll}
\hline Species & Status & $\begin{array}{c}\text { Size of } \\
\text { range }\end{array}$ & $\begin{array}{c}\text { Habitat } \\
\text { continuity }\end{array}$ & \multicolumn{2}{c}{ Threats } & Action \\
\cline { 5 - 7 } & & & Trade & HD & priority \\
\hline Ara militaris & Rare & Small & Patchy & V H & High & Critical \\
A. ararauna & Uncom & Medium & Discont & V H & Low & Hi-Crit \\
A. chloroptera & Com(loc) & Large & Discont & V H & Low & High \\
A. macao & Com(loc) & Large & Patchy & V H & Med. & High \\
\hline
\end{tabular}

Abbreviations: HD, habitat destruction; Uncom, uncommon; Com (loc), common locally; $\mathrm{V} \mathrm{H}$, very high; Discont, discontinuous.

We suggest that all of the larger macaws are high priority species (Table 4). The most critical of these is Ara militaris (Appendix I, CITES, a listing with which we concur). This species has a patchy and local distribution within Venezuela, and is generally rare within its range. Despite this, it is common in the national pet trade, which gives cause for concern.

A. ararauna has been virtually extirpated over much of its range in the Orinoco Delta over the last decade, where it has been heavily used for the international trade. Despite the threat of local extinction in the delta, there are viable populations remaining in Amazonas territory in southern Venezuela. A. macao (Appendix I, CITES) and $A$. chloroptera are both undergoing severe local pressure as well, but both have a far wider distribution and apparently higher habitat tolerance than either $A$. ararauna or $A$. militaris. While trade figures for the red macaws remain high, their immediate status is far superior to the other two.

The smaller macaws, $A$. severa, $A$. manilata and $A$. nobilis have recently been appearing in larger numbers in the international market (Gaski 1988). The markets in Venezuela are following this trend, and close attention should be drawn towards these species, since they are easily confused with parakeets.

Among the other psittacids of high priority, Hapalopsittaca amazonina is included in the ICBP world check-list of threatened birds. Although not common in the pet trade, its mountainous range in the states of Táchira and Mérida is being rapidly reduced by habitat destruction (Bisbal 1988). The protected areas within its range (Tama N.P. and Sierra Nevada N.P.) are among the most threatened in Venezuela. The status of the subspecies $H$. a. theresae is similar to that of $A$. mercenaria canipalliata since their ranges are virtually identical.

Deroptyus accipitrinus is a rare species in Venezuela that is apparently exported in fairly high numbers from Guyana (Nilsson 1985). This is disturbing, as the origin of the individuals is not known, and their natural condition warrants closer inspection (Strahl et al. in prep.). Several of the smaller Venezuelan Psittacidae also warrant closer attention. The three Aratinga and one Forpus species listed in Table 5 all have restricted ranges and patchy habitats within those ranges. None is well studied within the country and all are pet trade species. 
Table 5. Priority species within Venezuelan Psittacidae: genera Deroptyus, Hapalopsittaca, Aratinga, Forpus

\begin{tabular}{|c|c|c|c|c|c|c|}
\hline \multirow[t]{2}{*}{ Species } & \multirow[t]{2}{*}{ Status } & \multirow{2}{*}{$\begin{array}{l}\text { Size of } \\
\text { range }\end{array}$} & \multirow{2}{*}{$\begin{array}{c}\text { Habitat } \\
\text { continuity }\end{array}$} & \multicolumn{2}{|c|}{ Threats } & \multirow{2}{*}{$\begin{array}{l}\text { Action } \\
\text { priority }\end{array}$} \\
\hline & & & & Trade & $H D$ & \\
\hline H. amazonina & Endangered & Restricted & Patchy & Med. & V H & Critical \\
\hline D. accipitrinus & Rare (loc) & Medium & Contin. & High? & Med & High? \\
\hline A. pertinax tortugensis & Unknown & Restricted & Patchy? & $?$ & $?$ & High? \\
\hline A. solstitialis & Very rare & Restricted & Patchy & High? & High & High \\
\hline A. acuticaudata neoxena & Com (loc) & Restricted & Contin? & High & High? & High \\
\hline F. p. viridissimus & Com (loc) & Restricted & Contin? & High & Med & High \\
\hline
\end{tabular}

Abbreviations: $\mathrm{HD}$, habitat destruction; (loc), local; V H, very high; Contin, continuous.

\section{Discussion}

\section{The conservation status of Venezuelan Psittacidae}

The current level of trade in the Psittacidae in Venezuela is alarming, particularly in light of the complete national-level legal restrictions on commerce in these species. Despite their legal protection, many populations are under increasing pressure, a situation which is bound to become worse in the face of the current economic crisis in the country. While national agencies have become increasingly involved in controlling this trade, it is clear that additional funding and international coordination must be added to approach a reasonable level of effectiveness.

The estimated illegal exports of birds from the Orinoco Delta is an example of the need for international cooperation. The vast majority of these birds are destined for Guyana and Trinidad, yet no channels of communication for conservation purposes operate between Venezuela and these countries. We feel that the delta is the most critical point for protection measures of Psittacidae, and both national and international attention should be focused on this region.

Without concurrent enforcement of legal and monetary disincentives, there is little hope of reducing trade figures. Logistic support for confiscations has been virtually non-existent in Venezuela, and the fines levied for trafficking in birds are ridiculously low. For example, the maximum penalty (as of October 1988) for possession of any number of wild-caught birds in the Orinoco Delta is Bs. 1,000 (US \$30) with no mandatory jail term. This fee is equivalent to the local cost of one pair of amazon parrots and is, of course, paid immediately by illegal smugglers, who are then free.

Additional problems exist in the poor record-keeping systems of local authorities, the low level of training among enforcement personnel, and the lack of holding facilities for confiscated birds. On the rare occasions when confiscation reports are written up, the information on the species involved and their numbers is usually inaccurate. As a result, it is almost impossible to evaluate the quantities confiscated per species, and the majority of important data is usually lost. Due to a lack of holding facilities and established post-confiscation methodologies, the surviving birds are usually released at the site of confiscation and/or given away by local authorities. 
Law enforcement in the critical delta region is further complicated by the maze-like system of waterways and the low budget assigned to the National Guard and Navy to patrol the area (Barreto 1986). With only five boats to patrol an area of more than $40,000 \mathrm{~km}^{2}$ and a shortage of gasoline, the efforts of the National Guard in the area are severely limited. In the Perijá region in northwest Venezuela, another area of high trade, there is virtually no logistic support for enforcement, and social conditions prevent active protection measures.

Until recently there has been only minimal personnel available for control in major airports and tourist centres. Since 1988, however, a new governmental organization within the Ministry of the Environment has begun to work in conjunction with the National Guard to reduce the illegal trade of wild species. This group, PROFAUNA (a reorganization of the Wildlife Service), is composed primarily of professional biologists who are trained in field problems, wildlife management, and conservation of endangered species. Although much of their effort on the bird trade has been concentrated in Caracas and adjacent areas, they have recently begun field work in both enforcement and education in such areas as the Orinoco Delta and Margarita Island. With technical personnel present even in its highest positions, PROFAUNA is perhaps the best long-term hope to control trade in Psittacidae in Venezuela.

\section{Recommendations for psittacid species conservation in Venezuela}

Finally, we would like to propose some concrete recommendations for species research and habitat-level conservation. On the species level, we feel that the recommendations shown in Table 6 are of the highest priority. Many of these are included in the goals of our current programme, but specific in-depth projects in critical areas (such as the Orinoco Delta, Sierra de Perijá, and insular regions) or on critical species are also warranted.

Table 6. Recommendations for species research and conservation measures

1. Studies of the status, ecology and management of critical species, especially those in the genera Amazona, Ara, Aratinga, Hapalopsittaca.

2. More rigorous analyses of local and international trade mechanisms and trade routes, particularly for those species outlined in Tables 3-5.

3. Studies of insular species and island conservation problems. In particular, studies of the status and breeding biology of the endangered Amazona barbadensis are of high immediate priority, along with a regional education and enforcement campaign to curb trade in this species.

4. Educational campaigns for enforcement personnel, including the National Guard, park guards, and local authorities (posters, talks, handbooks of trade species and problems).

5. Local educational campaigns directed towards the rural and urban public, especially in areas of high trade, around existing protected areas, and concerning populations of critical species.

6. Development of adequate methodology to census and monitor psittacid populations in a variety of habitat types, and the incorporation of Psittacidae research into monitoring techniques in the design of management plans for reserves.

7. Strict national and international advisorship, control, and (when applicable) accreditation for breeding facilities for recuperation and reintroduction of Psittacidae.

8. Interchange of information on trade and international commerce between authorities in Venezuela, Trinidad, Guyana and Colombia, and the development of joint enforcement mechanisms. 
First, studies on the status and ecology of such species as $A$. barbadensis, $A$. festiva, the larger Ara species, $H$. amazonina, and others in Tables 3-5 should be stimulated beyond the general surveys included in our ongoing programme. In particular, these studies should be directed towards ecology, management, and the use of psittacids and other large frugivores in developing plans for protected areas.

Second, although we are beginning to analyse available figures on trade, National Guard confiscations and levels of international commerce in Psittacidae, more in-depth work is required. Trade routes should be quantitatively determined to aid enforcement. Many of the figures needed for this are buried in files and regional records, and a detailed review may reveal more definitive trends to be presented to national and international authorities.

Third, an in-depth study of island species is of highest priority, given the current condition of these birds. A. barbadensis is currently the focus of two projects on Margarita Island. The first of these is a study of its ecology and behaviour by Kirsten Silvius with support from FUDENA and Wildlife Conservation International (NYZS). The second is an educational programme to reduce local trade, developed by Patricia Márquez with support from Pro Vita Animalium, PROFAUNA-MARNR, and Wildlife Conservation International. This work requires expansion to other species on other islands nearby.

Fourth, a nationwide educational campaign for enforcement personnel on critical species and trade is an absolute necessity. This campaign can easily be incorporated into the training programme for National Guardsmen, park guards, and MARNR personnel, and can also be developed as a lecture series for local headquarters personnel. The field biologists of PROFAUNA may be the best teachers for such a campaign, which should include identification of critical species, a handbook of trade species and problems, the development of a common confiscation methodology, and a well-designed record-keeping system. These measures would be extremely successful at minimal cost.

Fifth, locally oriented public educational campaigns will be the most effective means of controlling regional commerce. With the proper design, these can also call national attention to the status of the Psittacidae and help to develop an awareness of the importance of these species in natural ecosystems. Such campaigns should be directed towards major centres of consumption (e.g. Caracas) as well as source areas.

Sixth, the Psittacidae are undervalued as ecological indicators of human disturbance (in the form of habitat destruction and the pet trade), and therefore along with most other large frugivorous birds they should be included in plans for monitoring and managing protected areas. For this to be effective, adequate methods for estimating their abundance need to be developed.

Seventh, we feel that breeding facilities for production of psittacids and reintroduction of critical species into natural ecosystems can be an effective aid to conservation. However, such facilities should be closely monitored by governmental officials and disinterested non-governmental third parties to ensure that they comply with their original and primary purpose. The commercial "laundering" of wild-caught birds through alleged "breeding centres" would have far-reaching negative effects on psittacid conservation in Venezuela.

Lastly, there is a near-total lack of information exchange in the region between 
Venezuelan authorities and neighbouring countries (particularly Guyana, Trinidad and Tobago, Colombia, and the Netherlands Antilles). A key component in the reduction of international trade in both threatened and other species will be the establishment of active dialogue and cooperative efforts among agencies in these countries.

\section{Recommendations for habitat-level conservation action}

In addition to the species-level recommendations, we outline habitat-level and national-level priorities in Table 7 . First, the alarming recent estimates of habitat destruction in certain key areas require more complete quantitative investigation. Remote-sensing methodology should be incorporated into conservation strategies for these areas to a far greater degree, and protection measures should be concentrated in areas of highest disturbance. In particular, the Andes and coastal cordilleras from Táchira through the Paria Peninsula require attention, as well as the Sierra de Perijá and forested regions north of the Orinoco.

Second and third, enforcement and education efforts should be directed primarily towards areas of high trade and those containing critical species, including the Orinoco Delta and island habitats (e.g. La Blanquilla, Margarita, La Tortuga). The delta area is the region of highest priority for reduction of illegal international trafficking in psittacids. Combined programmes of education and enforcement are the most important immediate actions that can be taken in the country at present. Points four and five, the development of scientific core-area reserves within existing forest reserves and the incorporation of the Psittacidae into national and regional management plans, are long-term measures that can ensure the future of these species within Venezuela. In addition, number five calls attention to the importance of the Psittacidae and other large frugivores as indicator species of human disturbance and as key components of Neotropical ecosystems, thereby promoting their conservation on a broader scale. These species can play a critical role in monitoring protected areas by serving as indicators of human disturbance.

Table 7. Recommendations for habitat-level research and conservation

1. Review of habitat destruction in key areas: Andean foothills, national parks, protected areas, and regions of high endemism or diversity.

2. Priority action for enforcement and education in the Orinoco Delta.

3. Concentration of efforts towards island habitats: declaration of La Blanquilla Island as a protected area, preservation of habitat in the form of public or private reserves on Margarita Island, review of the status of La Tortuga Island.

4. Creation of scientific reserves within existing forest reserves for studies of management and preservation of biological diversity, including economically and ecologically important species such as the Psittacidae.

5. The development of techniques and incorporation of the Psittacidae as management tools for monitoring habitats and protected areas. 


\section{Implementing conservation of the Psittacidae in Venezuela}

The feasibility of some of the above recommendations may appear at first glance to be questionable. However, many of the recommendations here are either included in or under study by our on-going project, sponsored by FUDENA, WCI-NYZS, ICBP, and USFWS. This project has received support from many different governmental and non-governmental agencies within Venezuela, and we are somewhat optimistic that, through a coordinated, multi-level approach by different groups, we may put many of our recommendations into practice.

The initiation of several of the recommended programmes can be both inexpensive and relatively rapid. In the case of PROFAUNA, considerable internal funding has already been directed towards enforcement and education. Our current work will provide baseline data for most species and regions within the country. With international attention and additional funding available for costeffective spin-off projects, we feel that the future may not look as bleak for Venezuelan Psittacidae as one might otherwise predict.

\section{Acknowledgements}

The authors would like to thank the organizers of the II Meeting of the International Parrot Specialist Group in Curitiba, Brazil, particularly P. Scherer and D. Bruning, for the invitation to present this paper, and Wildlife Conservation International, a division of the New York Zoological Society (WCI-NYZS) for supporting our attendance. S. Boher, J.G. Garcia, and J. Cabrera of the PROFAUNA division of the Venezuelan Ministry of the Environment (MARNR) shared data and thoughts on the manuscript. P. Bichier, J.L. Silva, P. Márquez, G. Basili, N. Windevoxhel, A. Morales, R. Israel, and M. Cuesta helped in the field components of the study. Tnte. Coronel Q. Helys Ramo, Myr. E. B. Méndez, and Capt. J. Marcano of the Venezuelan National Guard lent us unpublished data and logistic assistance in the Orinoco Delta. K. Silvius and P. Márquez provided unpublished data from projects on $A$. barbadensis. P. de Mieres, of the Venezuelan Federation of Ornithology, furnished data on trade. G. Medina commented on drafts of the manuscript. The work presented here is part of a field programme supported by Wildlife Conservation International-NYZS, Fundación para la Defensa de la Naturaleza (FUDENA), the International Council for Bird Preservation (Pan American Section), and the Office of International Affairs of the United States Fish and Wildlife Service. Additional equipment and logistic support was provided by the regional office of WCI/NYZS, the National Guard (Guarderia Ambiental), the Centro de Investigaciones Científicas of the Universidad de Oriente and PROFAUNA-MARNR.

\section{References}

Barreto, E. M. (1986) Problemáticas de la cacería y contrabando de extracción de aves de ornato en el Bajo Delta del Orinoco. Unpublished paper for the II Seminario de Guaraeria Ambiental, November 1986.

Bisbal, F. J. (1988) Impacto humano sobre los habitats de Venezuela. Interciencia 13: 226-232.

Cabrera, J. (in press) Problemática de la cacería furtiva de aves canoras y de ornato en la región del Delta del Orinoco. Proceedings 62nd Reunion SSC, Foto-Arte Arata, Caracas, Venezuela. 
Collar, N. J. and Andrew, P. (1988) Birds to watch: the ICBP world checklist of threatened birds. Cambridge, U.K.: International Council for Bird Preservation (Techn. Publ. 8).

DeCivrieux, M. (1980) Los Cumanagotos y sus vecinos. Pp. 233-239 in W. Coppens, ed. Los aborigenes de Venezuela. Caracas: Fundación La Salle de Ciencias Naturales (Monogr. 26).

Emlen, J.T. (1971) Population densities of birds derived from transect counts. Auk 88: 323-342.

Forshaw, J. (1978) The parrots of the world. Second edition. Melbourne: Lansdowne Editions.

Gaski, A. L. (1988) "Miniature" macaws enter trade. Traffic (U.S.A.) 8(1): 20.

Gorzula, S. and Medina-Cuervo, G. (1986) La fauna silvestre de la cuenca del río Caroni y el impacto del hombre, evaluación y perspectivas. Interciencia 11: 317-324.

Hernández, F. A. (1988) Programa nacional de regularización de las áreas naturales protegidas en Venezuela. Unpublished paper for the Seminario Internacional sobre la Planificación, Administración y Manejo de Áreas Naturales Protegidas.

Ley de Protección a la Fauna Silvestre (1970) Gaceta Oficial No. 29289, Caracas, Venezuela.

Meyer de Schauensee, R. and Phelps, Jr., W. H. (1978) A guide to the birds of Venezuela. Princeton, N.J.: Princeton University Press.

Nilsson, G. (1985) Importation of birds into the U.S. 1980-1984 (Vol. 2). Washington, D.C.: Animal Welfare Institute.

Novo, I. T. (1986) Las explotaciones forestales en Venezuela: caso de las áreas bajo regimen de administración especial. Unpublished paper from Master's course: Geopolítica y Recursos Naturales.

Reynolds, R. T., Scott, J. M. and Nussbaum, R. A. (1980) A variable circular-plot method for estimating bird numbers. Condor 82: 309-313.

Ridgely, R. S. (1981) The current distribution and status of mainland Neotropical parrots. Pp. $233-384$ in R. F. Pasquier, ed. Conservation of New World parrots. Washington, D.C.: Smithsonian Institution Press for the International Council for Bird Preservation (Techn. Publ. 1).

Snyder, N. F. R., Wiley, J. W. and Kepler, C. B. (1987) The parrots of Luquillo: natural history and conservation of the Puerto Rican Parrot. Los Angeles: Western Foundation of Vertebrate Zoology.

Strahl, S. D., Desenne, P. and Jiménez, J. L. (in prep.) Observations on the behavior and foraging of the hawk-headed parrot, Deroptyus accipitrinus, in southern Venezuela.

Thomsen, J. B. (1988) Guyana and Suriname establish quotas on parrot exports. Parrotletter 1: 11-12.

\section{PHILIP DESENNE}

Fundación para la Defensa de la Naturaleza, Apartado 70376, Caracas 1071-A, Venezuela.

STUART D. STRAHL

Wildlife Conservation International, New York Zoological Society, 185th St. and Southern Blvd., Bronx, NY 10460, U.S.A. 